\title{
Geology and Assessment of Undiscovered Oil and Gas Resources of the Lena-Vilyui Basin Province, 2008
}

Chapter $\mathrm{V}$ of

The 2008 Circum-Arctic Resource Appraisal

Professional Paper 1824

U.S. Department of the Interior

U.S. Geological Survey 
Cover. Eocene strata along the north side of Van Keulenfjorden, Svalbard, include basin-floor fan, marine slope, and deltaic to fluvial depositional facies. The age and facies of these strata are similar to Tertiary strata beneath the continental shelves of Arctic Eurasia, thus providing an analog for evaluating elements of those petroleum systems. Relief from sea level to top of upper bluff is approximately 1,500 feet. Photograph by David Houseknecht. 


\section{Geology and Assessment of Undiscovered Oil and Gas Resources of the Lena-Vilyui Basin Province, 2008}

By Timothy R. Klett and Janet K. Pitman

Chapter V of

The $\mathbf{2 0 0 8}$ Circum-Arctic Resource Appraisal

Edited by T.E. Moore and D.L. Gautier

Professional Paper 1824 


\title{
U.S. Department of the Interior RYAN K. ZINKE, Secretary
}

\section{U.S. Geological Survey William H. Werkheiser, Acting Director}

\author{
U.S. Geological Survey, Reston, Virginia: 2017
}

For more information on the USGS — the Federal source for science about the Earth, its natural and living resources, natural hazards, and the environment-visit https://www.usgs.gov or call 1-888-ASK-USGS.

For an overview of USGS information products, including maps, imagery, and publications, visit https://store.usgs.gov.

Any use of trade, firm, or product names is for descriptive purposes only and does not imply endorsement by the U.S. Government.

Although this information product, for the most part, is in the public domain, it also may contain copyrighted materials as noted in the text. Permission to reproduce copyrighted items must be secured from the copyright owner.

Suggested citation:

Klett, T.R., and Pitman, J.K., 2017, Geology and assessment of undiscovered oil and gas resources of the Lena-Vilyui Basin Province, 2008, chap. V of Moore, T.E., and Gautier, D.L., eds., The 2008 Circum-Arctic Resource Appraisal: U.S. Geological Survey Professional Paper 1824, 17 p., https://doi.org/10.3133/pp1824V.

ISSN 2330-7102 (online) 


\section{The 2008 Circum-Arctic Resource Appraisal}

\section{Chapters}

A. Introduction to the 2008 Circum-Arctic Resource Appraisal (CARA) Professional Paper By Donald L. Gautier and Thomas E. Moore

B. Methodology for Assessment of Undiscovered Oil and Gas Resources for the 2008 Circum-Arctic Resource Appraisal

By Ronald R. Charpentier

\section{North America}

C. Geology and Assessment of Undiscovered Oil and Gas Resources of the Chukchi Borderland Province, 2008

By Kenneth J. Bird and David W. Houseknecht

D. Geology and Assessment of Undiscovered Oil and Gas Resources of the Hope Basin

Province, 2008

By Kenneth J. Bird, David W. Houseknecht, and Janet K. Pitman

E. Geology and Assessment of Undiscovered Oil and Gas Resources of the Arctic Alaska Petroleum Province, 2008

By David W. Houseknecht, Kenneth J. Bird, and Christopher P. Garrity

F. Geology and Assessment of Undiscovered Oil and Gas Resources of the Yukon Flats Basin Province, 2008

By Kenneth J. Bird and Richard G. Stanley

G. Geology and Assessment of Undiscovered Oil and Gas Resources of the Northwest Canada Interior Basins Province, Arctic Canada, 2008

By Marilyn E. Tennyson and Janet K. Pitman

H. Geology and Assessment of Undiscovered Oil and Gas Resources of the Franklinian Shelf Province, Arctic Canada and North Greenland, 2008

By Marilyn E. Tennyson and Janet K. Pitman

I. Geology and Assessment of Undiscovered Oil and Gas Resources of the Sverdrup Basin Province, Arctic Canada, 2008

By Marilyn E. Tennyson and Janet K. Pitman

\section{Greenland}

J. Geology and Assessment of Undiscovered Oil and Gas Resources of the West GreenlandEast Canada Province, 2008

By Christopher J. Schenk 
K. Geology and Assessment of Undiscovered Oil and Gas Resources of the East Greenland Rift Basins Province, 2008

By Donald L. Gautier

\section{North Atlantic Ocean}

L. Geology and Assessment of Undiscovered Oil and Gas Resources of the Jan Mayen Microcontinent Province, 2008

By Thomas E. Moore and Janet K. Pitman

\section{Eurasia}

M. Geology and Assessment of Undiscovered Oil and Gas Resources of the Mezen' Basin Province, 2008

By Timothy R. Klett and Janet K. Pitman

N. Geology and Assessment of Undiscovered Oil and Gas Resources of the Timan-Pechora Basin Province, Russia, 2008

By Christopher J. Schenk

0. Geology and Assessment of Undiscovered Oil and Gas Resources of the East Barents Basins Province and the Novaya Zemlya Basins and Admiralty Arch Province

By Timothy R. Klett

P. Geology and Assessment of Undiscovered Oil and Gas Resources of the North Kara Basins and Platforms Province, 2008

By Timothy R. Klett and Janet K. Pitman

0. Geology and Assessment of Undiscovered Oil and Gas Resources of the Northern West Siberian Mesozoic Composite Total Petroleum System of the West Siberian Basin Province, Russia, 2008

By Christopher J. Schenk

R. Geology and Assessment of Undiscovered Oil and Gas Resources of the Yenisey-Khatanga Basin Province, 2008

By Timothy R. Klett and Janet K. Pitman

S. Geology and Assessment of Undiscovered Oil and Gas Resources of the Northwest Laptev Sea Shelf Province, 2008

By Timothy R. Klett and Janet K. Pitman

T. Geology and Assessment of Undiscovered Oil and Gas Resources of the Lena-Anabar Basin Province, 2008

By Timothy R. Klett and Janet K. Pitman 
U. Geology and Assessment of Undiscovered Oil and Gas Resources of the Tunguska Basin Province, 2008

By Christopher J. Wandrey and Timothy R. Klett

V. Geology and Assessment of Undiscovered Oil and Gas Resources of the Lena-Vilyui Basin Province, 2008

By Timothy R. Klett and Janet K. Pitman

W. Geology and Assessment of Undiscovered Oil and Gas Resources of the Laptev Sea Shelf Province, 2008

By Timothy R. Klett and Janet K. Pitman

X. Geology and Assessment of Undiscovered Oil and Gas Resources of the Zyryanka Basin Province, 2008

By Timothy R. Klett and Janet K. Pitman

Y. Geology and Assessment of Undiscovered Oil and Gas Resources of the East Siberian Sea Basin Province, 2008

By Kenneth J. Bird, David W. Houseknecht, and Janet K. Pitman

Z. Geology and Assessment of Undiscovered Oil and Gas Resources of the Vilkitskii Basin Province, 2008

By Kenneth J. Bird, David W. Houseknecht, and Janet K. Pitman

AA. Geology and Assessment of Undiscovered Oil and Gas Resources of the Long Strait Province, Russian High Arctic, 2008

By Kenneth J. Bird, David W. Houseknecht, and Janet K. Pitman

\section{Arctic Ocean}

BB. Geology and Assessment of Undiscovered Oil and Gas Resources of the Amerasia Basin Petroleum Province, 2008

By David W. Houseknecht, Kenneth J. Bird, and Christopher P. Garrity

CC. Geology and Assessment of Undiscovered Oil and Gas Resources of the LomonosovMakarov Province, Central Arctic Ocean, 2008

By Thomas E. Moore, Kenneth J. Bird, and Janet K. Pitman

DD. Geology and Assessment of Undiscovered Oil and Gas Resources of the Eurasia Basin Province, Eastern Arctic Ocean, 2008

By Thomas E. Moore and Janet K. Pitman 


\section{Contents}

Abstract

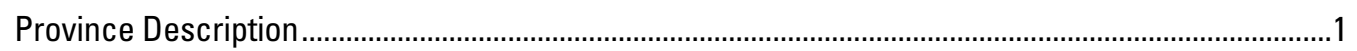

Province-Boundary Definition.....................................................................................................

Petroleum Occurrence................................................................................................................

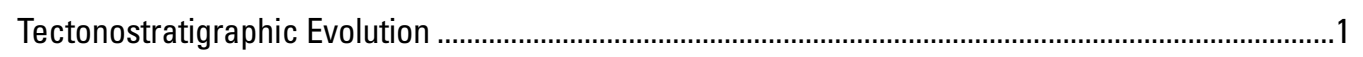

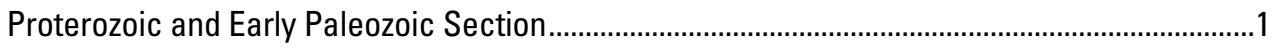

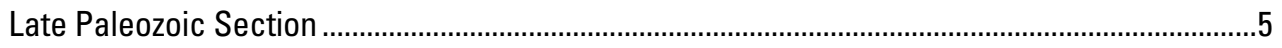

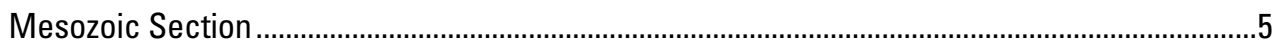

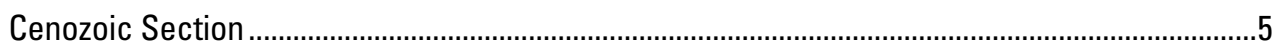

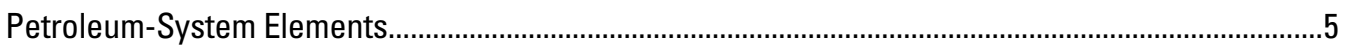

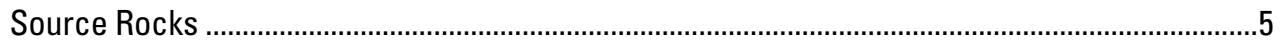

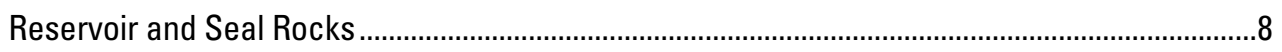

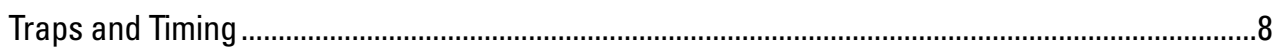

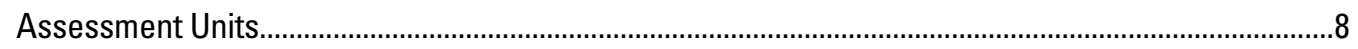

Northern Priverkhoyansk Foredeep Assessment Unit......................................................................

Geologic Analysis of Assessment-Unit Probabilities ...................................................................

Geologic Analogs for Assessment.......................................................................................

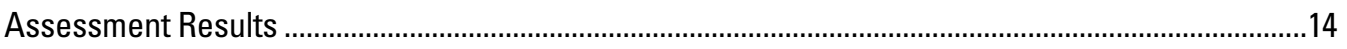

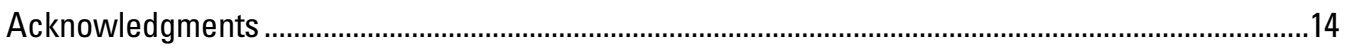

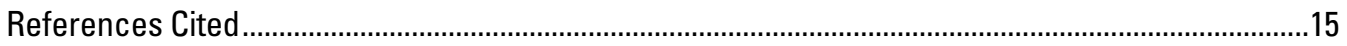

\section{Appendix}

[Available for download at https://doi.org/10.3133/pp1824X]

1. Input Data for the Northern Priverkhoyansk Foredeep Assessment Unit 


\section{Figures}

1. Map of the Arctic, showing location of the Lena-Vilyui Basin Province and assessment

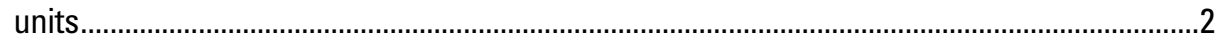

2. Map showing major structural features, approximate depth to economic basement, and location of geologic cross sections and petroleum-system models used in assessment of the Lena-Vilyui Basin Province.................................................................................................

3. Regional geologic cross sections in the Lena-Vilyui Basin Province ....................................4

4. Lithostratigraphic column and total-petroleum-system events chart for the Lena-Vilyui

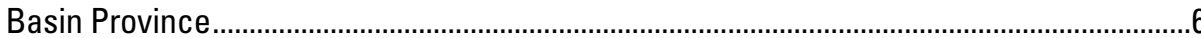

5. Burial-history model for pseudowells in the Northern Priverkhoyansk Foredeep in the Lena-Vilyui Basin Province depicting thermal maturity

\section{Tables}

1. Provinces used as geologic analogs in assessment of the Northern Priverkhoyansk Foredeep Assessment Unit.

2. Field densities, median oil and gas field sizes, and exploration maturities of geologic analogs used in Northern Priverkhoyansk Foredeep Assessment Unit assessment.........12

3. World statistics for porpoduct ratios, ancillary data, and depths

4. Assessment results of the Lena-Vilyui Basin Province (conventional undiscovered resources). 



\title{
Chapter V
}

\section{Geology and Assessment of Undiscovered Oil and Gas Resources of the Lena-Vilyui Basin Province, 2008}

\author{
By Timothy R. Klett and Janet K. Pitman
}

\begin{abstract}
The U.S. Geological Survey (USGS) recently assessed the potential for undiscovered oil and gas resources of the LenaVilyui Basin Province, north of the Arctic Circle, as part of the Circum-Arctic Resource Appraisal program. The province is in the Russian Federation and is situated between the Verkhoyansk fold-and-thrust belt and the Siberian craton. The one assessment unit (AU) defined for this study - the Northern Priverkhoyansk Foredeep AU—was assessed for undiscovered, technically recoverable resources. The estimated mean volumes of undiscovered resources for the Northern Priverkhoyansk Foredeep in the Lena-Vilyui Basin Province are $\sim 400$ million barrels of crude oil, 1.3 trillion cubic feet of natural gas, and 40 million barrels of natural-gas liquids, practically all (99.49 percent) of which is north of the Arctic Circle.
\end{abstract}

\section{Province Description}

\section{Province-Boundary Definition}

The Lena-Vilyui Basin Province consists of the LenaVilyui Basin, which is situated along the eastern margin of the Siberian craton in east-central Russia (figs. 1,2). Only the part of the province north of the Arctic Circle is considered in this study, the southern boundary of which is placed at an east-northeast trending fault shown by Persits and Ulmishek (2003) and Grantz and others (2011) near the location of the Arctic Circle (figs. 1, 2). Geologically, this area lies west of the Verkhoyansk fold-and-thrust belt, south of the Olenek fold zone, and encompasses the northern part of the Priverkhoyansk foreland basin.

\section{Petroleum Occurrence}

Although six new-field wildcat wells and three stratigraphic test wells have been drilled in the study area (fig. 1), no fields have been discovered in the northern part of the Lena-Vilyui Basin Province as of this study (IHS Energy Group, 2007). In the Lena-Vilyui Basin Province south of the Arctic Circle, known fields contain mostly natural gas and condensates in upper Paleozoic and Mesozoic clastic rocks (Vagin and others, 1987; Sokolov, 1989). Extensive degraded petroleum (called "bitumen," not assessed in this study) deposits crop out along the margins of the Olenek High (Ivanov, 1979; Parfenov, 1985), but no fields have been discovered on the high.

\section{Tectonostratigraphic Evolution}

The Lena-Vilyui Basin Province was a system of Proterozoic rifts upon which a carbonate platform and shelf developed. The platform and shelf composed a passive margin that existed until the Cretaceous, when it was deformed by the west-vergent Verkhoyansk fold-and-thrust belt. Deposition during and after the deformation occurred in a foreland basin setting west of the Verkhoyansk belt. Geologic cross sections (fig. 3) show the characteristics of the basin fill and structure of the adjacent thrust belt.

\section{Proterozoic and Early Paleozoic Section}

The Lena-Vilyui Basin Province originated by rifting along the Siberian craton during the late Proterozoic (Riphean), followed by subsidence and deposition on an early Paleozoic carbonate shelf (Gusev and others, 1985; Vagin and others, 1987). Riftrelated sedimentary deposits include hundreds to thousands of meters of siliciclastic and clastic-carbonate materials (Safronov and Bodunov, 1987).

Uplift, deformation, and erosion during late Proterozoic time resulted in the formation of an angular unconformity between Riphean and overlying Vendian rocks (Zonenshain and others, 1990; Ulmishek, 2001). The uplift and erosion deposited clastic rocks in the lower part of the Vendian section and isolated the southern part of the Siberian craton, allowing a large shallow 


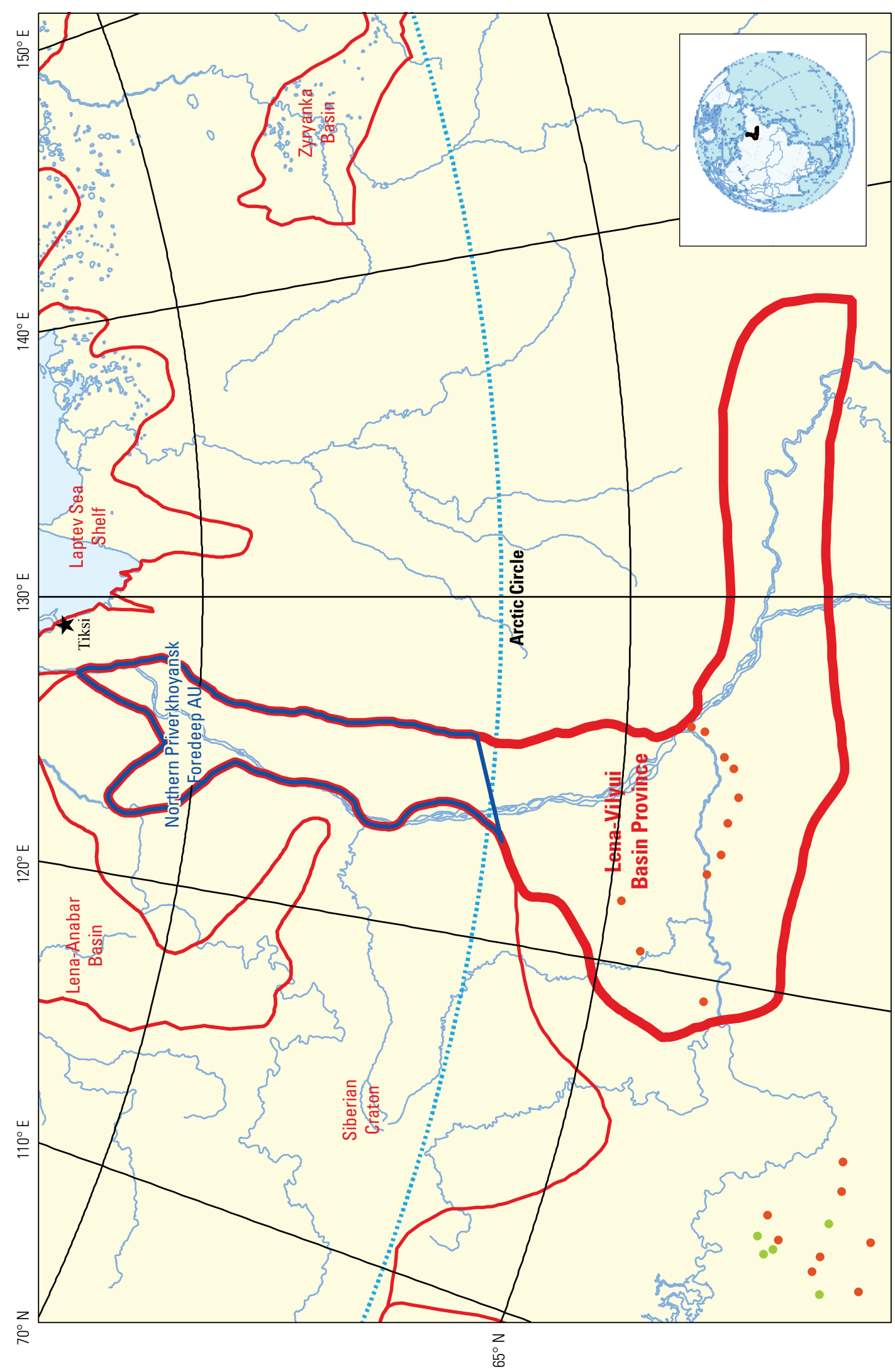

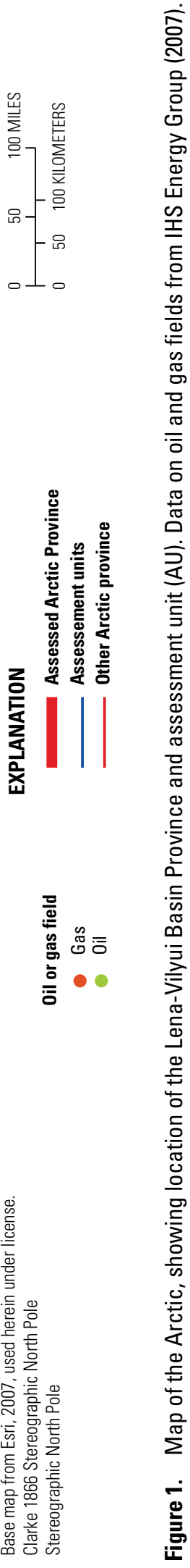




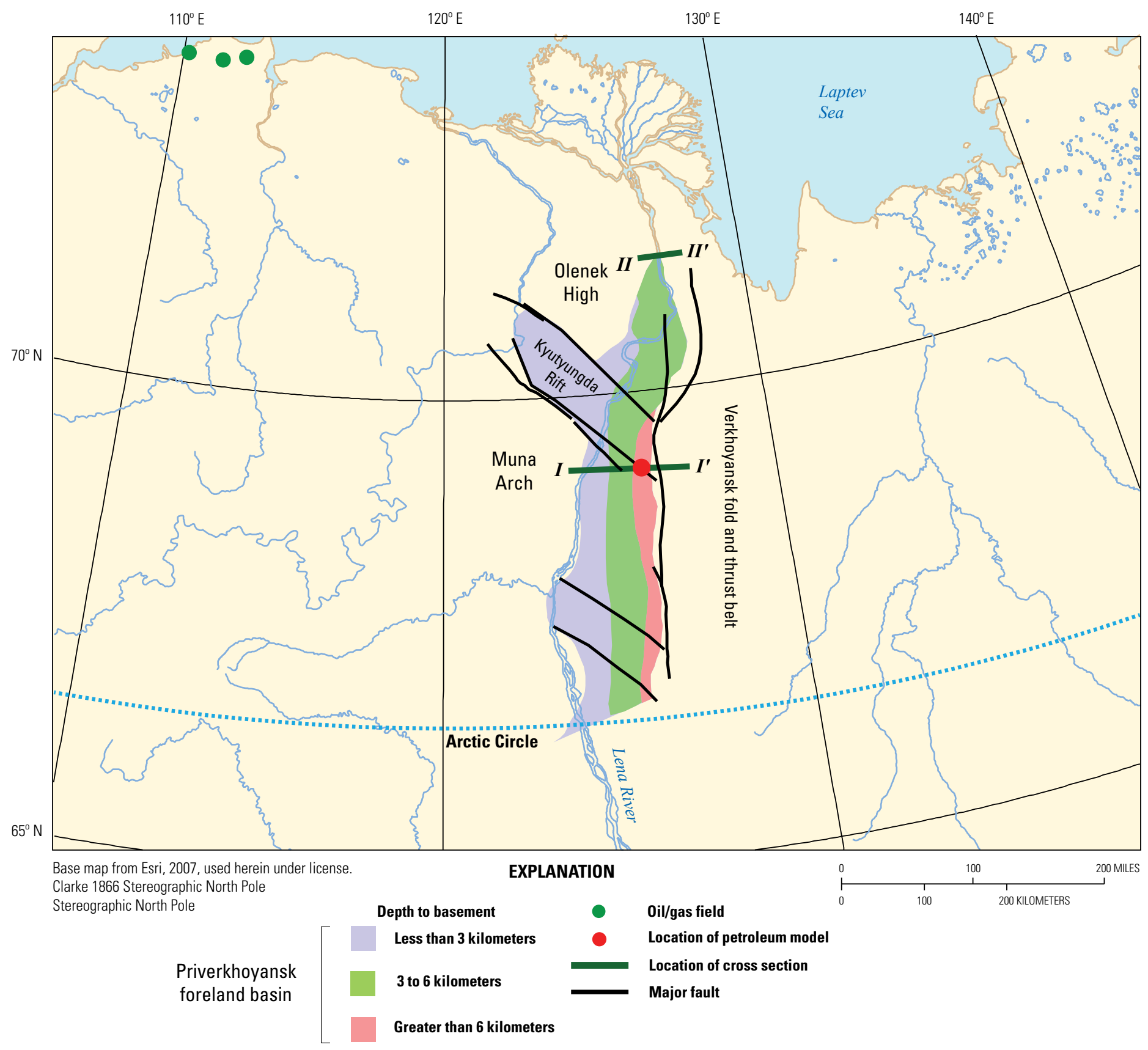

Figure 2. Map showing major structural features, approximate depth to economic basement, and location of geologic cross sections and petroleum-system models used in assessment of the Lena-Vilyui Basin Province. Data from Persits and Ulmishek (2003) and IHS Energy Group (2007). 
$\boldsymbol{A}$

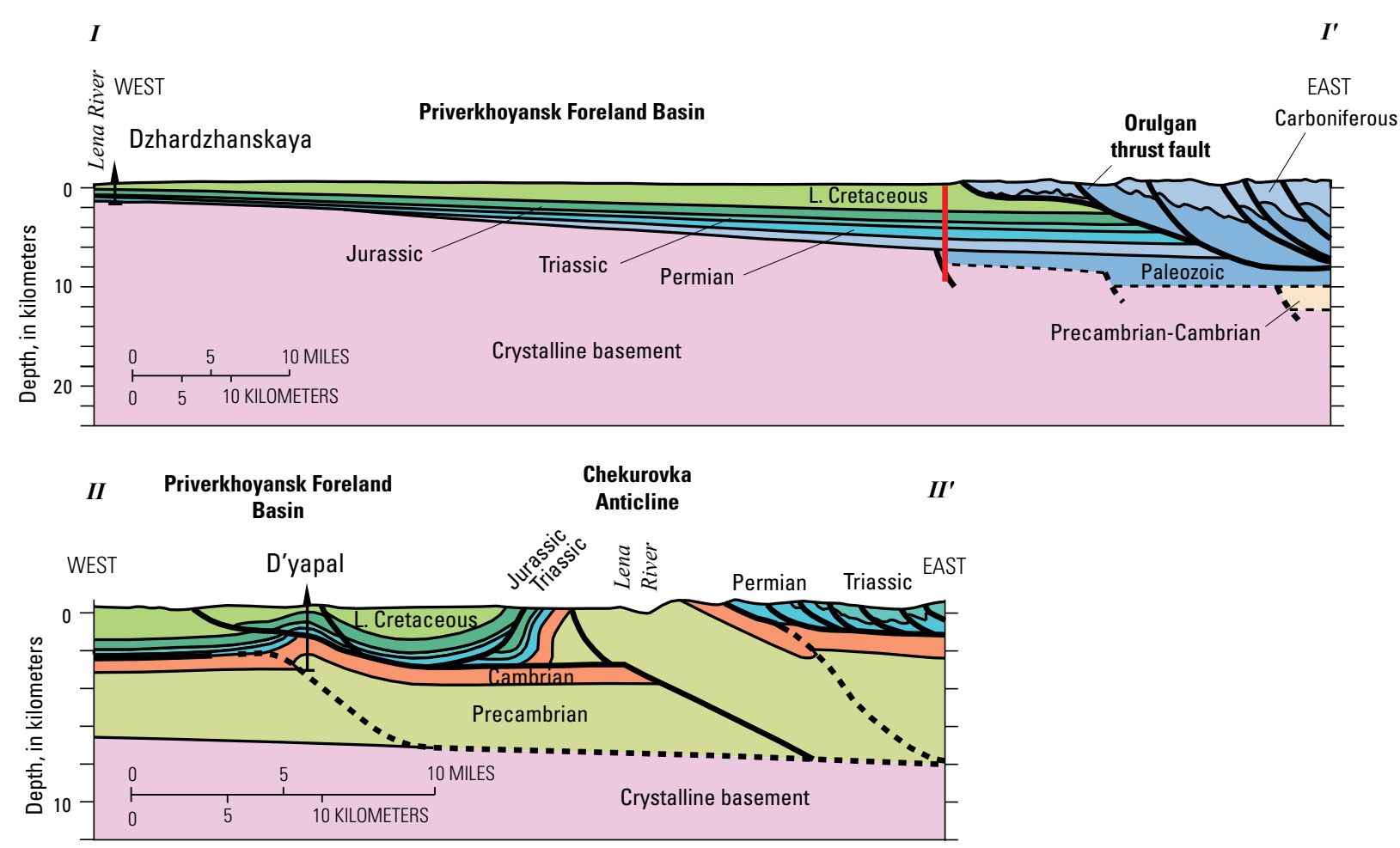

B. East margin of siberian craton

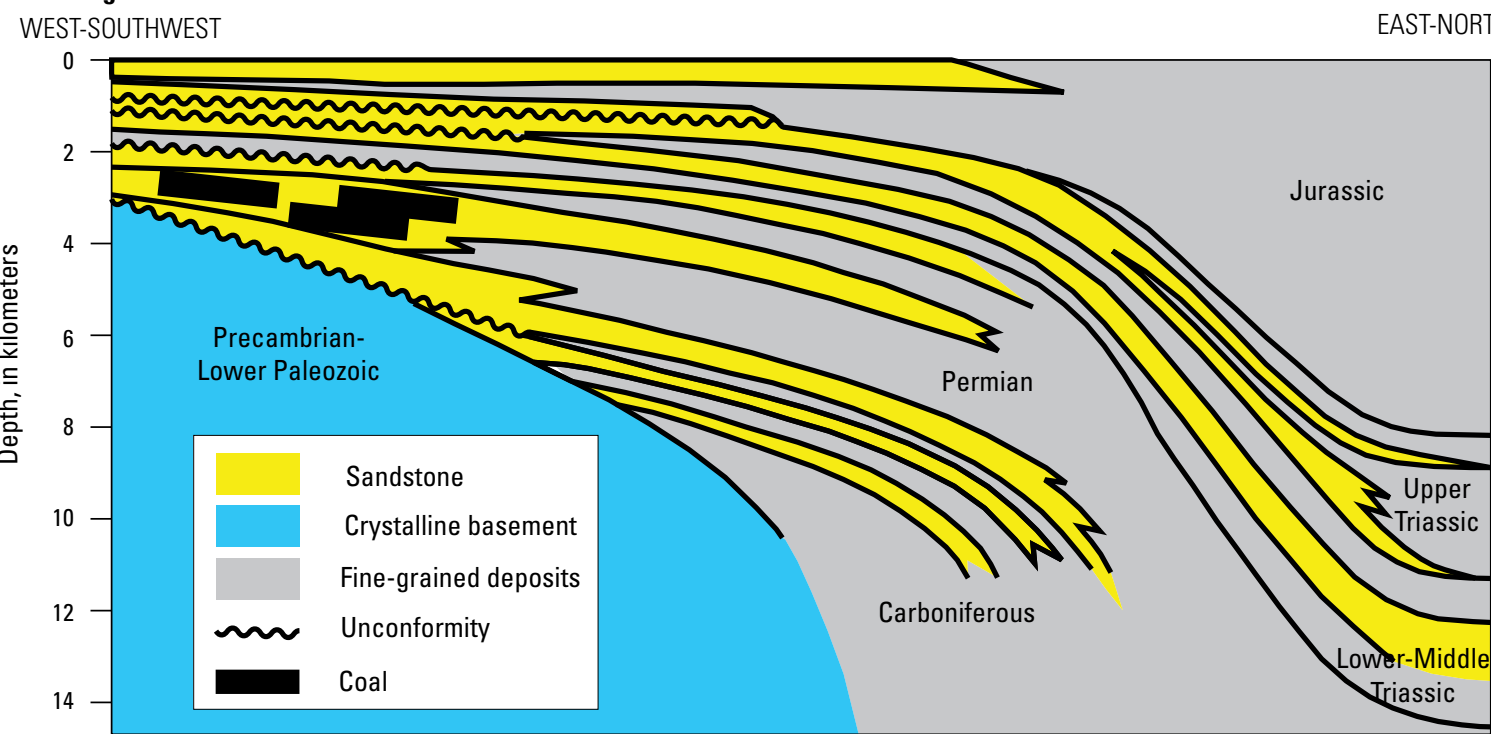

Figure 3. Regional geologic cross sections in the Lena-Vilyui Basin Province. Vertical red line denotes location of pseudowell used for petroleum-generation model (see fig. 2). Modified from Parfenov and Prokopiev (1993) and Parfenov and others (1995). 
lagoon in which evaporites were deposited during the late Vendian and Early Cambrian (Zonenshain and others, 1990). The lagoon was rimmed by carbonate shelves on its present-day southeast and southwest sides, and separated from the open ocean by a zone of reefs on the present-day north and northeast (Ulmishek, 2001). In the Lena-Vilyui Basin, as much as $3.5 \mathrm{~km}$ of Vendian and Lower Cambrian carbonates, evaporites, and some clastic rocks were deposited (Safronov and Bodunov, 1987), which represent lagoonal conditions in the west and marine conditions in the east.

Carbonate platform and shelf conditions continued along the rifted passive margins of the Siberian craton throughout the early Paleozoic. Organic-rich (bituminous) mudstone was deposited beyond the reefs in the northern and northeastern parts of the craton during the Early and Middle Cambrian. In the Lena-Vilyui Basin, $\sim 1 \mathrm{~km}$ of Middle and Upper Cambrian carbonate strata were deposited (Safronov and Bodunov, 1987). Upper Paleozoic rocks are absent across most of the Siberian craton (Ulmishek, 2001), and little, if any, sedimentary materials were deposited in the Lena-Vilyui Basin.

\section{Late Paleozoic Section}

The Siberian craton drifted northward from the Devonian to the Triassic, moving from a warm dry climate at low to middle latitudes into a cooler humid climate at higher latitudes (Zonenshain and others, 1990). During the Devonian, the craton passed over a mantle plume (hotspot), causing rifting and magmatism along the present-day southeastern and northern margins of the craton and forming rift grabens (aulacogens) beneath the Lena-Vilyui Basin, including the Kyutyungda rift graben (fig. 2), and other rift grabens beneath the present-day Khatanga Saddle and the Yenisey-Khatanga Basin, which lie outside the area of figures 1 and 2 . At that time, basaltic magma intruded the Lena-Vilyui Basin area, and kimberlite dikes intruded across the craton (Zonenshain and others, 1990). These rift grabens are presumed to be reactivated Precambrian rifts (Gusev and others, 1985; Sokolov, 1989).

In the Vilyui Basin, the rift grabens contain Devonian and lower Carboniferous evaporites, carbonates, and clastic rocks (Sokolov, 1989). Organic-rich mudstone might have been deposited within the grabens before evaporite deposition (G.F. Ulmishek, oral commun., 2006). Opening of an ocean basin by rifting from the late Carboniferous to the Triassic resulted in subsidence as the eastern margin of the Siberian craton developed into a passive divergent margin (Vagin and others, 1987; Sokolov, 1989).

As the Siberian craton moved to higher latitudes, carbonate deposition changed to clastic deposition (Zonenshain and others, 1990). The margins of the craton remained passive during the late Paleozoic and early Mesozoic, and thick successions of deltaic, paralic, nearshore marine, and submarine-fan strata were deposited along the Lena-Vilyui Basin (see fig. 5; Vagin and others, 1987; Sokolov and Yapaskurt, 1988; Sokolov, 1989; Zonenshain and others, 1990). Upper Carboniferous and Permian rocks, including turbidites, were deposited in deep-marine conditions.
As deposition and progradation continued, the marginal basin shallowed, and thick Permian to Cretaceous shallow-marine and continental clastic rocks were deposited (Vagin and others, 1987).

\section{Mesozoic Section}

Extension, magmatism, and volcanism occurred during the formation of a triple junction along the present-day northwestern margin of the Siberian craton in the late Permian-Early Triassic (Girshgorn, 1996; Kontorovich and others, 1994; Allen and others, 2006). Rifting and emplacement of basaltic magma occurred as far east as the Lena-Vilyui Basin (Vagin and others, 1987; Sokolov and Yapaskurt, 1988).

Collision of the Omolon and Chukotka microcontinents (Kolyma block) with the eastern margin of the Siberian craton during the Late Jurassic and Early Cretaceous formed the Verkhoyansk fold-and-thrust belt (Sokolov and Yapaskurt, 1988; Zonenshain and others, 1990). The fold-and-thrust belt conformed to the outlines of the Devonian rift systems (Zonenshain and others, 1990). The Priverkhoyansk foreland basin formed along the thrust front of the Verkhoyansk foldand-thrust belt. A thick section of alternating marine and continental clastic sedimentary rocks with coal was deposited during Late Jurassic and Early Cretaceous time (Vagin and others, 1987; Sokolov and Yapaskurt, 1988).

\section{Cenozoic Section}

The main phase of folding and thrusting occurred during the Cretaceous and Cenozoic, depositing coarse orogenic clastic sediments in structural lows (Vagin and others, 1987). Tectonic quiescence during the Paleogene was followed by uplift of 1.5 to $2 \mathrm{~km}$ during the Oligocene to Quaternary (Sokolov, 1989).

\section{Petroleum-System Elements}

Because of presumed mixing of petroleum, a single Proterozoic-Paleozoic-Mesozoic composite total petroleum system (TPS) was identified for the Lena-Vilyui Basin Province. A lithostratigraphic column and TPS events chart with petroleum-system elements is shown in figure 4 .

\section{Source Rocks}

Main potential source rocks include Precambrian and Cambrian oil-prone organic-rich carbonates and mudstone, as well as Permian gas-prone carbonaceous mudstone in the Northern Priverkhoyansk foreland basin. In the southern part of the province the main source rocks are presumed to be a Permian gas-prone coal-bearing interval that contains 1 to 3.8 weight percent total organic carbon (TOC) in mudstone (Izosimova and others, 1988; Sokolov, 1989). Minor source 
The 2008 Circum-Arctic Resource Appraisal

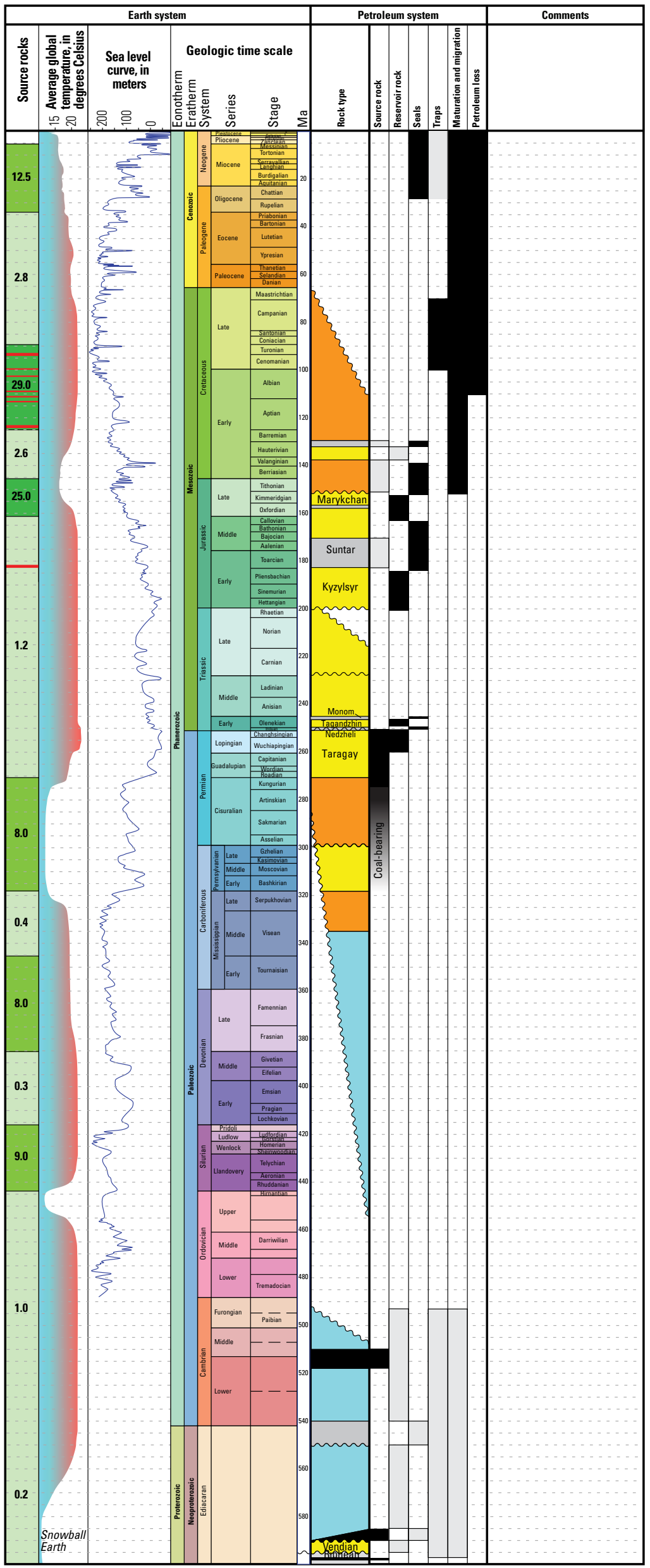

\begin{tabular}{|c|}
\hline \multicolumn{1}{|c|}{ EXPLANATION } \\
Rock type \\
$\square \quad$ Continental clastic rocks \\
$\square \quad$ Nearshore clastic rocks \\
$\square \quad$ Offshore clastic rocks \\
$\square \quad$ Organic-rich mudstone \\
$\square \quad$ Volcanic and volcaniclastic rocks \\
$\square \quad$ Carbonate rocks \\
Petroleum system \\
$\square \quad$ Identified presence \\
$\square \quad$ Possible presence \\
- Ocean anoxic event \\
\hline
\end{tabular}

Figure 4. Lithostratigraphic column and total-petroleum-system events chart for the Lena-Vilyui Basin Province. Source rocks column shows the percent of the world's total petroleum reserves generated by source (modified from Ulmishek and Klemme, 1990). Average global temperature data is from Frakes and others (1992) and Barrett (2003). Sea level curve is from Golonka and Kiessling (2002) and Hardenbol and others (1998). Geologic time scale is that of Gradstein and others (2004). Data from Safronov and Bodunov (1987), Vagin and others (1987), Izosimova and others (1988), Sokolov and Yapaskurt (1988), Sokolov (1989), Bakhturov and others (1990), and Baranova (1996). 

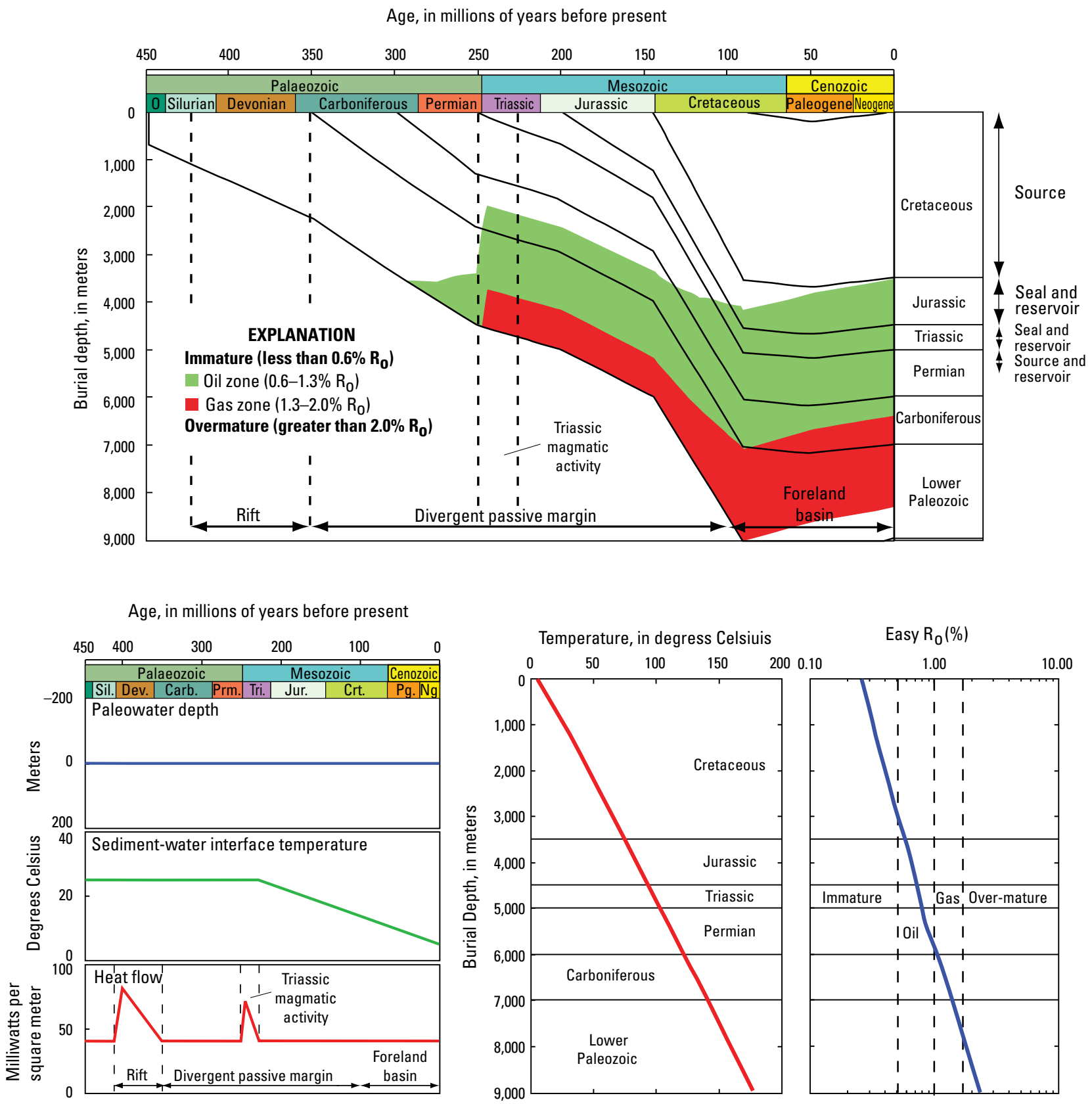

$$
\text { Easy } R_{0}(\%)
$$

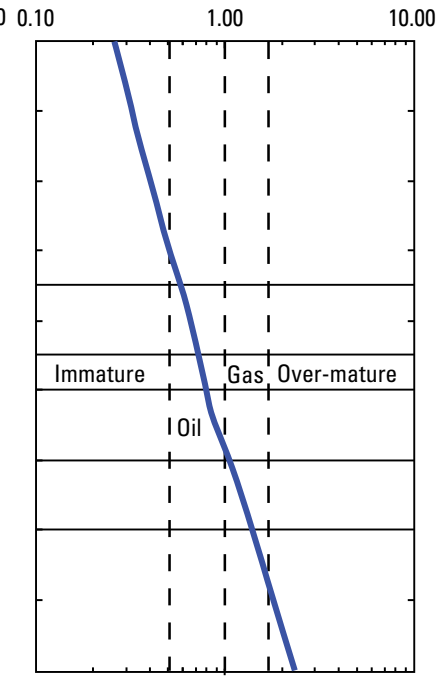

Figure 5. Burial-history model for pseudowells in the Northern Priverkhoyansk Foredeep Assessment Unit in the Lena-Vilyui Basin Province depicting thermal maturity. See figure 2 for locations of wells. Ro, vitrinite reflectance, in percent (\%). Data from Duchkov and others (1982), Frolov and others (1987), Izosimova and others (1988), Sokolov and Yapaskurt (1988), Parfenov and Prokopiev (1993). Petromod references are from Wygrala (1989), Sweeney and Burnham (1990), Integrated Exploration Systems (2008). 
rocks in this area are gas prone, including Jurassic (maximum 2.2 weight percent TOC in the upper part), Lower Cretaceous (maximum 1.6 weight percent TOC), and possibly Triassic mudstone (Sokolov, 1989). The presence of bitumen deposits along the northern and eastern margins of the Olenek High (Ivanov, 1979; Parfenov, 1985), presumably from Precambrian and Cambrian source rocks, indicate that the northern part of the province might be oil prone rather than gas prone as in the southern part of the province. Gas fields discovered to date are located in the southern part of the basin.

On the basis of petroleum-generation models, Permian and Mesozoic source rocks began to generate petroleum by the end of the Mesozoic (fig. 5). These source rocks are presently in the gas-generation window in deeper parts of the basin and in the oil window in shallower areas. Maturation of Proterozoic and Cambrian source rocks is modeled to have occurred during the Paleozoic, assuming that a sufficient thickness of Paleozoic rocks was deposited; otherwise, these rocks would have entered the oil-generation window during Mesozoic time due to burial beneath the Cretaceous foredeep deposits.

\section{Reservoir and Seal Rocks}

Reservoir rocks in the Northern Priverkhoyansk foreland basin are assumed to be similar to those in the southern part of the Lena-Vilyui Basin Province. Lithic and arkosic Permian through Jurassic sandstones become predominantly arkosic in the Upper Jurassic and Lower Cretaceous intervals (Sokolov, 1989), sourced primarily from the Siberian craton. In the northernmost part of the foreland basin, these clastic rocks are coarser grained in the west along the Olenek High, fining eastward into more distal marine environments. Sedimentary patterns changed by Early Cretaceous (Barremian) time with the eastward advance of the Verkhoyansk fold-and-thrust belt toward the Siberian craton. Clastic sedimentary rocks contain material sourced from the Verkhoyansk fold-andthrust belt and fine westward (Parfenov and others, 1995). Several reservoir and seal pairs are known in southern part of the Lena-Vilyui Basin Province and occur in the upper Permian, Lower Triassic, and Lower through Upper Jurassic stratigraphic intervals. Potential reservoir and seal pairs in the northern part of the province include those within the Middle and Upper Triassic, Middle and Upper Jurassic, and Lower Cretaceous sections (Vagin and others, 1987; Sokolov, 1989). Although Precambrian and Cambrian clastic rocks and carbonates with mudstone seals have not been explored in the study area, they could have accumulated Precambrian- and Cambrian-sourced petroleum. Cambrian through Silurian carbonates and Devonian evaporites would act as seals.

\section{Traps and Timing}

Potential traps in the Northern Priverkhoyansk foreland basin include simple or faulted anticlines and thrust-faultrelated structures related to the collision of the Kolyma block with the Siberian craton during the Late Cretaceous, and updip stratigraphic pinchouts (Baranova, 1986; Vagin and others, 1987; Sokolov, 1989; Kontorovich, 1994). However, most of the pre-Cretaceous source-rock maturation and petroleum generation occurred by Late Cretaceous time, before and during trap formation. The foreland basin is a relatively undeformed monocline, with few traps between the fold and thrust belt and the updip basin margin.

According to petroleum-generation models for the adjacent Lena-Anabar Basin (see chapter T of this volume), maturation of Proterozoic and Cambrian source rocks likely occurred during the Paleozoic, assuming that a sufficient thickness of Paleozoic rocks was deposited. However, the probability of preservation would likely be low because of pre-Permian erosion. Otherwise, Proterozoic and Cambrian source rocks, as well as Permian and Mesozoic source rocks, generated petroleum during the Mesozoic before and during compressional deformation along the Verkhoyansk fold-andthrust belt. Although some accumulated petroleum was probably lost, generation may have continued during trap formation (Sokolov and Yapaskurt, 1988).

Petroleum migrated vertically along faults, laterally over short distances into reservoirs juxtaposed to source rocks by fault displacements, or laterally updip over long distances through permeable carrier beds from deeper parts of the foredeep to the basin margin (Parfenov, 1985). Bitumen accumulations along the Olenek High are evidence of such long-distance migration (Parfenov, 1985) and are assumed to indicate that little petroleum was captured in sedimentary traps in the basin.

\section{Assessment Units}

One AU, the Northern Priverkhoyansk Foredeep AU, was defined for the Lena-Vilyui Basin Province. For this study, an $\mathrm{AU}$ is defined as a volume of rock within the TPS that has similar geologic characteristics. The estimated numbers and sizes of undiscovered oil and gas fields in this AU are reported in appendix 1 , and the geologic-analog data used to evaluate the AUs are summarized in tables 1 and 2.

\section{Northern Priverkhoyansk Foredeep Assessment Unit}

The Northern Priverkhoyansk Foredeep AU coincides with the foreland basin north of the Arctic Circle, and includes strata that onlap updip onto the Siberian craton (the Olenek High and the Muna Arch), which forms the west boundary of the AU. The AU is bounded on the north and east by the Verkhoyansk foldand-thrust belt, and on the south by the edge of the Lena-Vilyui rift graben (figs. 1,2). Stratigraphically, the AU includes the entire sedimentary section from Proterozoic through Mesozoic. 
The AU area of $\sim 56,000 \mathrm{~km}^{2}$ is completely onshore, and more than 99 percent is north of the Arctic Circle.

The AU began as a rift basin during the Precambrian and was later reactivated in the early and middle Paleozoic. The Kyutyunda rift part of the AU contains Devonian and lower Carboniferous strata associated with rifting. The AU later developed into an eastward-facing passive divergent margin. Upper Carboniferous and Permian turbidites are overlain by a thick Permian through Cretaceous marine, shallow-marine, and continental clastic succession. Jurassic and Cretaceous deformation created a foreland basin in front of the present-day Verkhoyansk fold and thrust belt.

\section{Geologic Analysis of Assessment-Unit Probabilities}

No oil or gas fields have been discovered in the Northern Priverkhoyansk Foredeep AU as of 2007, and so source, reservoir, and seal rocks and trap configurations can only be inferred. The probability that the AU contains at least one field equal to or larger than the minimum size of 50 million barrels of oil equivalent (MMBOE) is 40 percent (0.40). Input distributions and probabilities for the Northern Priverkhoyansk Foredeep AU are reported in appendix 1 and summarized below.

Charge Probability.-A charge probability of 1.0 was estimated because large amounts of bitumen occur along the updip limits of the AU.

Rock Probability.-A rock probability of 0.8 was estimated because the presence of reservoirs, seals, and traps is likely but unknown.

Timing and Preservation Probability.-A timing and preservation probability of 0.5 was estimated because pre-Cretaceous source rocks were predicted to enter the petroleum-generation window before and during Cretaceous deformation and trap formation. Bitumen deposits along the north and east margins of the Siberian craton indicate that some generated oil might not have been trapped.

\section{Geologic Analogs for Assessment}

Two analog datasets were chosen from the USGS Analog Database (Charpentier and others, 2008): (1) foreland basins (24 analogs) and (2) rifted passive margins and foreland basins with mixed clastic and carbonate depositional systems (15 analogs). The analog datasets were used to estimate the numbers and sizes of undiscovered fields (tables 1,2). Both datasets contain discovered oil and gas fields larger than the minimum size (50 MMBOE) defined for this assessment. The analog categories include extensional and compressional structures and traps with carbonate and clastic depositional systems (table 1). Four AUs are common to both analog datasets.
Numbers of Undiscovered Fields.-The numbers of undiscovered oil and gas fields was estimated by comparing field densities (estimated numbers of undiscovered fields plus numbers of discovered fields larger than 50 MMBOE per $1,000 \mathrm{~km}^{2}$ ) of the two analog datasets (table 2). The median and maximum densities of discovered fields are 0.2 and 1.1 fields per $1,000 \mathrm{~km}^{2}$, respectively, whereas the median and maximum densities of discovered plus undiscovered fields are 0.3 and 1.6 fields per $1,000 \mathrm{~km}^{2}$, respectively. Minimum, medium, and maximum densities of $0.02,0.1$, and 0.9 , respectively, were used in this assessment. These densities are slightly lower than those in the analog dataset because no economic discoveries were made in the AU despite exploration, and a carbonate shelf might not have existed over the entire study area. The total minimum, median, and maximum numbers of undiscovered fields are 1, 7, and 50, respectively (see appendix. 1). An oil/gas mixture of 0.5 $( \pm 0.2)$ was assumed because of the possible contributions from both gas-prone Mesozoic source rocks and oil-prone Proterozoic and Paleozoic source rocks. The estimated minimum, median, and maximum numbers of undiscovered oil fields are 1,4 , and 35 , respectively, and of undiscovered gas fields are 1, 4, and 35, respectively (see appendix. 1).

Sizes of Undiscovered Fields. - The minimum, median, and maximum sizes of undiscovered oil and gas fields in the Northern Priverkhoyansk Foredeep AU are reported in appendix 1. The minimum sizes of undiscovered oil and gas fields defined for the $\mathrm{AU}$ are 50 million barrels (MMB) of crude oil and 300 billion cubic feet (BCF) of natural gas (6 BCF equals $1 \mathrm{MMBOE}$ ). The median sizes of undiscovered oil and gas fields in the AU are $125 \mathrm{MMB}$ of crude oil and $500 \mathrm{BCF}$ of natural gas. The median size of undiscovered oil fields is approximately equal to the mean size in the analog dataset, $130 \mathrm{MMBOE}$, but the median size of undiscovered gas fields is considerably smaller because traps for natural gas in this AU might not be efficient (table 1). Low-probability maximum sizes of undiscovered oil and gas fields in the $\mathrm{AU}$ are 2,500 MMB of oil and 1,000 BCF of gas, allowing for the probability of a large oil field within the Proterozoic and Paleozoic section.

Expected Maximum Size of Undiscovered Fields.-The expected maximum sizes of oil and gas fields $400 \mathrm{MMB}$ of oil and $100 \mathrm{BCF}$ of gas, respectively, are based on the distribution of sizes of discovered fields in the analog dataset, particularly the median size of discovered fields.

Petroleum Composition and Properties of Undiscovered Fields.-Coproducts and petroleum-quality properties were estimated from global statistics (table 3 ) and petroleum properties of the nearby Baikal-Patom Foldbelt Riphean-Craton Margin Vendian AU (province number 12100101). 
Table 1. Provinces used as geologic analogs in assessment of the Northern Priverkhoyansk Foredeep Assessment Unit.

[Analog data from Charpentier and others (2008)]

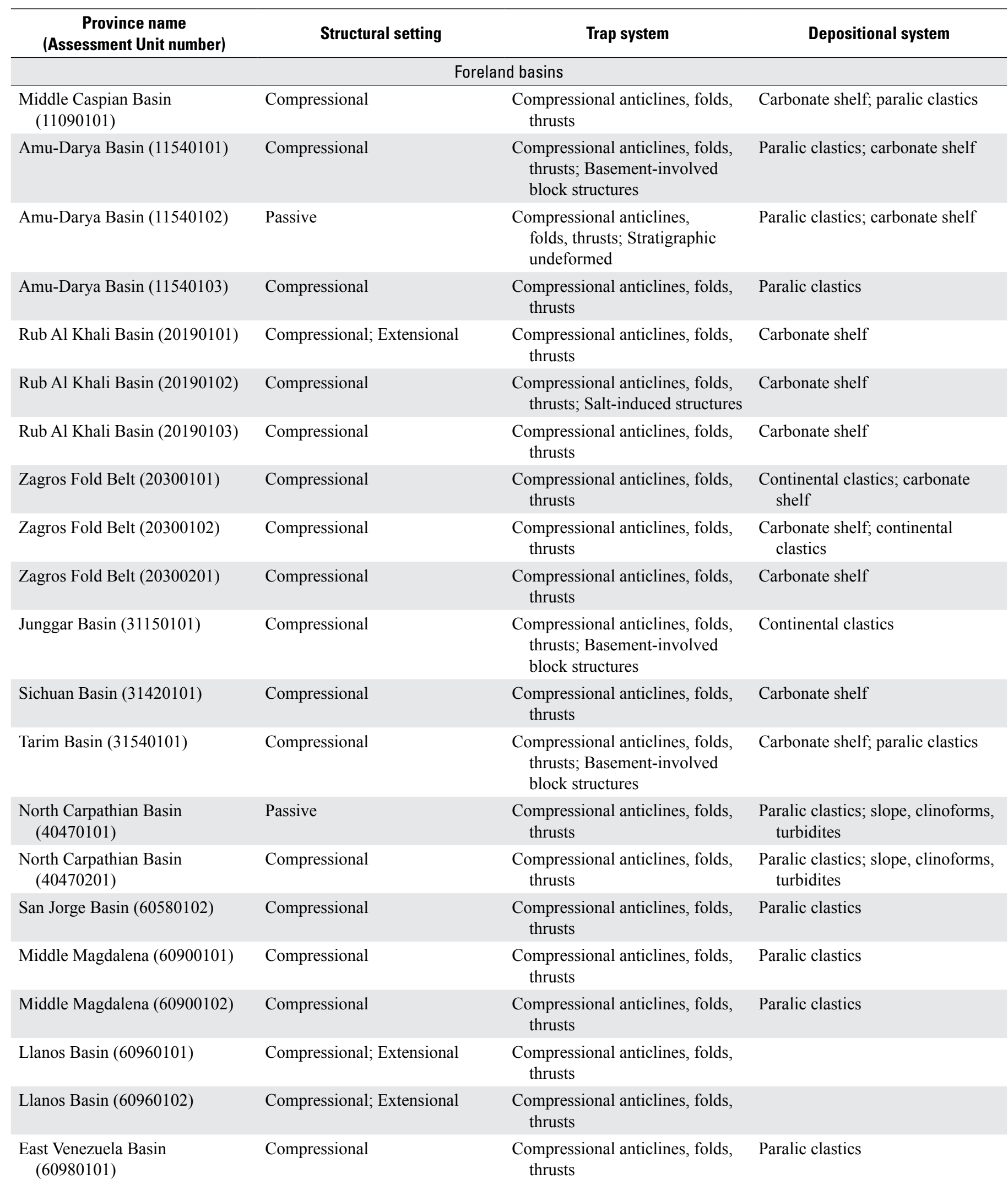


Table 1. Provinces used as geologic analogs in assessment of the Northern Priverkhoyansk Foredeep Assessment Unit.—Continued

[Analog data from Charpentier and others (2008)]

\begin{tabular}{|c|c|c|c|}
\hline $\begin{array}{c}\text { Province name } \\
\text { (Assessment Unit number) }\end{array}$ & Structural setting & Trap system & Depositional system \\
\hline $\begin{array}{l}\text { East Venezuela Basin } \\
\quad(60980102)\end{array}$ & Compressional & $\begin{array}{l}\text { Compressional anticlines, folds, } \\
\text { thrusts }\end{array}$ & Paralic clastics \\
\hline Maracaibo Basin (60990102) & Compressional & $\begin{array}{l}\text { Compressional anticlines, folds, } \\
\text { thrusts }\end{array}$ & Paralic clastics \\
\hline Deformed Belt (61170101) & Compressional & $\begin{array}{l}\text { Compressional anticlines, folds, } \\
\text { thrusts }\end{array}$ & Carbonate shelf \\
\hline \multicolumn{4}{|c|}{ Rifted passive margins } \\
\hline $\begin{array}{l}\text { Timan-Pechora Basin } \\
\quad(10080102)\end{array}$ & Compressional & $\begin{array}{l}\text { Basement-involved block struc- } \\
\text { tures; Paleogeomorphic }\end{array}$ & Paralic clastics; carbonate shelf \\
\hline $\begin{array}{l}\text { Timan-Pechora Basin } \\
\quad(10080103)\end{array}$ & Compressional & $\begin{array}{l}\text { Compressional anticlines, folds, } \\
\text { thrusts }\end{array}$ & Paralic clastics; carbonate shelf \\
\hline Volga-Ural Region (10150101) & Passive & $\begin{array}{l}\text { Basement-involved block struc- } \\
\text { tures; Paleogeomorphic }\end{array}$ & Paralic clastics; carbonate shelf \\
\hline Volga-Ural Region (10150102) & Compressional & $\begin{array}{l}\text { Basement-involved block struc- } \\
\text { tures }\end{array}$ & Paralic clastics; carbonate shelf \\
\hline $\begin{array}{l}\text { Middle Caspian Basin } \\
\text { (11090101) }\end{array}$ & Compressional & $\begin{array}{l}\text { Compressional anticlines, folds, } \\
\text { thrusts }\end{array}$ & Carbonate shelf; paralic clastics \\
\hline Amu-Darya Basin (11540101) & Compressional & $\begin{array}{l}\text { Compressional anticlines, folds, } \\
\text { thrusts; Basement-involved } \\
\text { block structures }\end{array}$ & Paralic clastics; carbonate shelf \\
\hline Nepa-Botuoba Arch (12100101) & Compressional & $\begin{array}{l}\text { Basement-involved block struc- } \\
\text { tures; Stratigraphic unde- } \\
\text { formed }\end{array}$ & Paralic clastics; Carbonate shelf \\
\hline $\begin{array}{l}\text { Ma'Rib-Al Jawf/Masila Basin } \\
\quad \text { (20040101) }\end{array}$ & Extensional & $\begin{array}{l}\text { Extensional grabens and other } \\
\text { structures related to normal } \\
\text { faulting }\end{array}$ & Paralic clastics; Carbonate shelf \\
\hline Fahud Salt Basin (20160201) & Compressional; Extensional & $\begin{array}{l}\text { Compressional anticlines, folds, } \\
\text { thrusts }\end{array}$ & $\begin{array}{l}\text { Paralic clastics; carbonate shelf } \\
\text { margin, reefs }\end{array}$ \\
\hline Zagros Fold Belt (20300101) & Compressional & $\begin{array}{l}\text { Compressional anticlines, folds, } \\
\text { thrusts }\end{array}$ & $\begin{array}{l}\text { Carbonate shelf margin, reefs, } \\
\text { slope, clinoforms, turbidites }\end{array}$ \\
\hline Zagros Fold Belt (20300102) & Compressional & $\begin{array}{l}\text { Compressional anticlines, folds, } \\
\text { thrusts }\end{array}$ & $\begin{array}{l}\text { Continental clastics; carbonate } \\
\text { shelf }\end{array}$ \\
\hline Pelagian Basin (20480101) & Compressional; Extensional & $\begin{array}{l}\text { Extensional grabens and other } \\
\text { structures related to normal } \\
\text { faulting; Transtensional and } \\
\text { transpressional }\end{array}$ & $\begin{array}{l}\text { Carbonate shelf; continental } \\
\text { clastics }\end{array}$ \\
\hline Pelagian Basin (20480201) & Compressional; Extensional & $\begin{array}{l}\text { Extensional grabens and other } \\
\text { structures related to normal } \\
\text { faulting; Transtensional and } \\
\text { transpressional }\end{array}$ & Carbonate shelf; paralic clastics \\
\hline Tarim Basin (31540101) & Compressional & $\begin{array}{l}\text { Compressional anticlines, folds, } \\
\text { thrusts; Basement-involved } \\
\text { block structures }\end{array}$ & Paralic clastics; carbonate shelf \\
\hline \multirow[t]{2}{*}{ Bombay (80430101) } & Extensional & $\begin{array}{l}\text { Basement-involved block struc- } \\
\text { tures; Stratigraphic unde- } \\
\text { formed }\end{array}$ & Paralic clastics; carbonate shelf \\
\hline & & & $\begin{array}{l}\text { Paralic clastics; carbonate shelf } \\
\text { margin, reefs }\end{array}$ \\
\hline
\end{tabular}


Table 2. Field densities, median oil and gas field sizes, and exploration maturities of geologic analogs used in Northern Priverkhoyansk Foredeep Assessment Unit assessment.

[Analog data from Charpentier and others (2008). Asterisk (*), not reported in analog database. Gas volumes are nonassociated. MMBOE, million barrels of oil equivalent; $\mathrm{MMB}$, million barrels; $\mathrm{BCF}$, billion cubic feet]

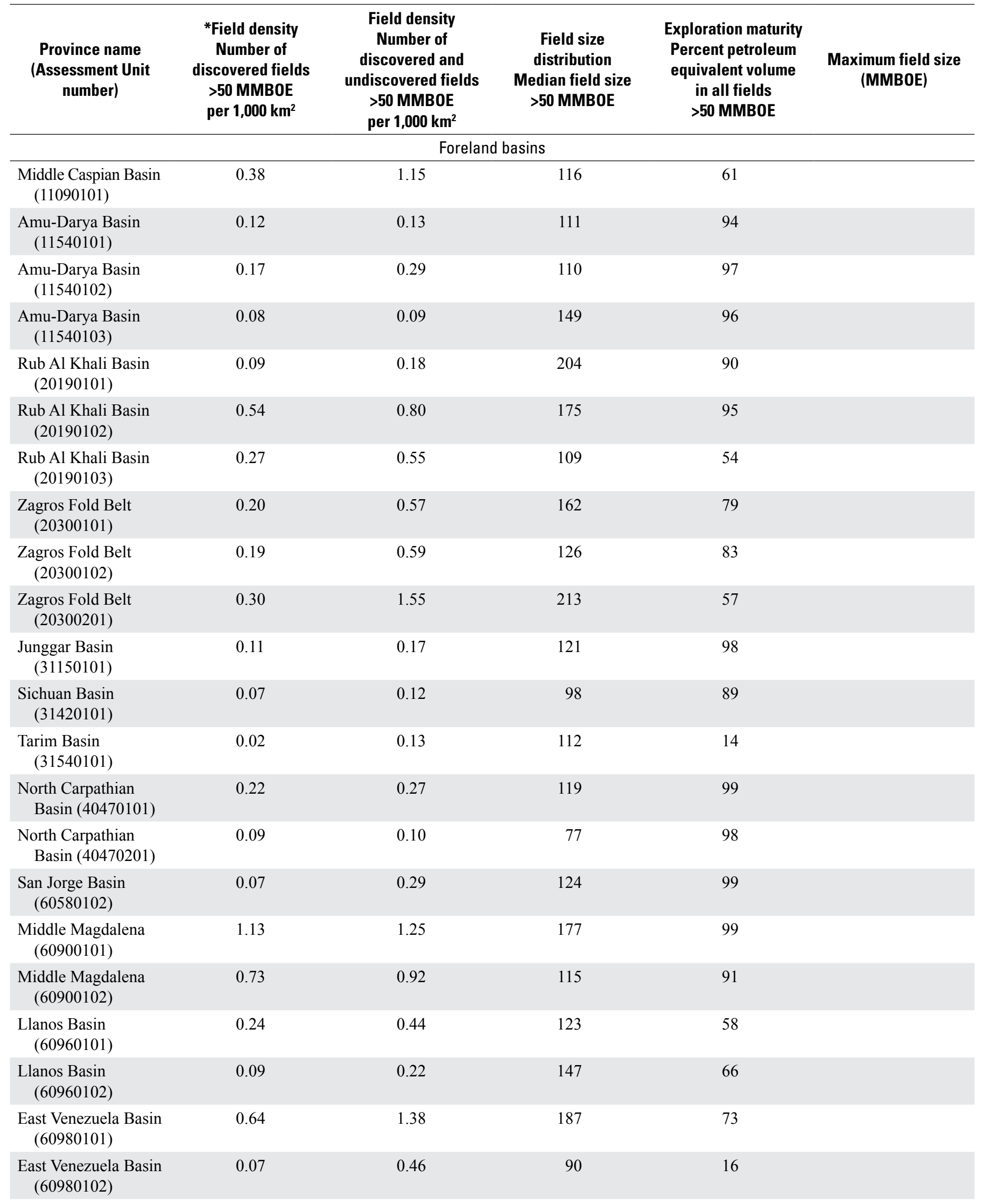


Table 2. Field densities, median oil and gas field sizes, and exploration maturities of geologic analogs used in Northern Priverkhoyansk Foredeep Assessment Unit assessment.-Continued

[Analog data from Charpentier and others (2008). Asterisk (*), not reported in analog database. Gas volumes are nonassociated. MMBOE, million barrels of oil equivalent; MMB, million barrels; $\mathrm{BCF}$, billion cubic feet]

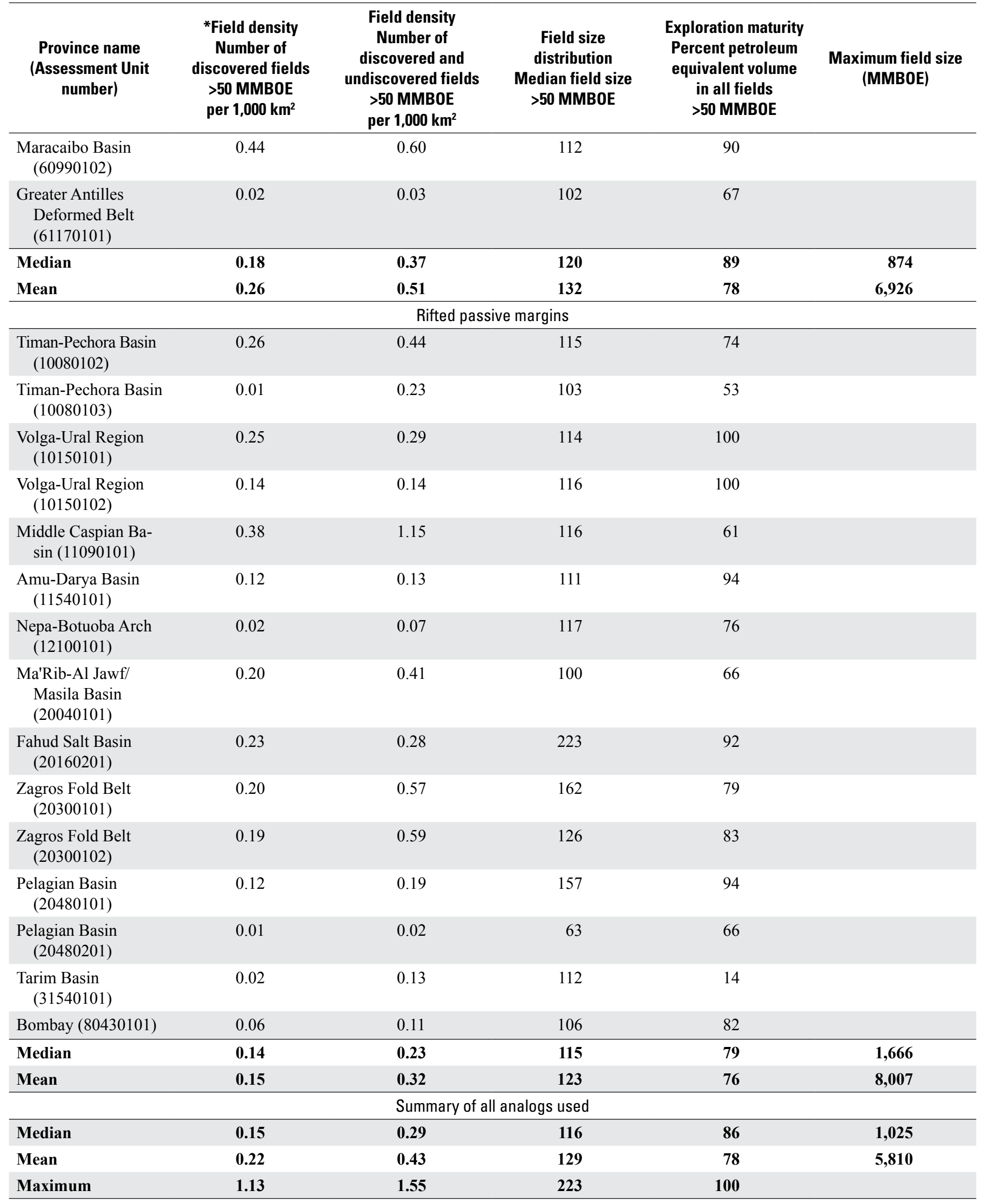




\section{Assessment Results}

The assessment results for the Northern Priverkhoyansk Foredeep AU are summarized in table 4. Estimates represent undiscovered, technically recoverable, conventional petroleum resources.

The mean undiscovered crude-oil resource in the Northern Priverkhoyansk Foredeep AU (north of the Arctic Circle) is $377 \mathrm{MMB}$, with a 95-percent-confidence probability (F95) of $0 \mathrm{MMB}$ and an F5 of 1,732 MMB. Given the probability of 0.40 for an oil and gas field of minimum size, a probablility of 50 percent $(0.50)$ that no crude-oil or naturalgas resources exist is estimated for this AU (table 4). The mean volume of undiscovered nonassociated natural-gas resource is 1,039 $\mathrm{BCF}$, with an $\mathrm{F} 95$ of $0 \mathrm{BCF}$ and an $\mathrm{F} 5$ of $4,319 \mathrm{BCF}$. The maximum expected size of an undiscovered oil field is $\sim 393 \mathrm{MMB}$, and the maximum expected size of an undiscovered gas field is $\sim 619 \mathrm{BCF}$.

The total estimated mean volume of undiscovered petroleum resources in the Northern Priverkhoyansk Foredeep in the Lena-Vilyui Basin Province north of the Arctic Circle is the same as for the Northern Priverkhoyansk Foredeep AU (table 4). Additional statistics are provided in table 4.

The geologic probabilities of the AUs in this study were determined on the basis of a consideration of the geology of this province but also from the geologic probabilities assigned to AUs during the assessment of all Arctic basins. Thus, the probabilities were consistently applied throughout the Arctic in this assessment project.

\section{Acknowledgments}

We are grateful to the USGS Library staff for their help in obtaining rare, hard-to-find geologic articles from the Russian scientific literature. We also thank Feliks Persits for Geographic Information System (GIS) support, and Donald L. Gautier and Gregory F. Ulmishek for their reviews and comments, which greatly improved the manuscript.

Table 3. World statistics for porpoduct ratios, ancillary data, and depths.

[Data from Charpentier and others, 2008]

\begin{tabular}{|c|c|c|c|}
\hline Variable & Minimum & Median & Maximum \\
\hline \multicolumn{4}{|c|}{ Coproduct ratios } \\
\hline $\begin{array}{l}\text { Ratio of natural gas to crude oil in oil accumulations } \\
\text { (cubic feet per barrel) }\end{array}$ & 100 & 1,000 & 20,000 \\
\hline $\begin{array}{l}\text { Ratio of natural gas liquids to natural gas in oil accumulations } \\
\text { (barrels per thousand cubic feet) }\end{array}$ & 5 & 25 & 85 \\
\hline $\begin{array}{l}\text { Ratio of natural gas liquids to natural gas in gas accumulations } \\
\text { (barrels per thousand cubic feet) }\end{array}$ & 5 & 25 & 75 \\
\hline \multicolumn{4}{|c|}{ Ancillary data for oil accumulations } \\
\hline API gravity (degrees) & 20 & 38 & 55 \\
\hline Viscosity (centipoise) & 0.01 & 3 & 30 \\
\hline Sulfur content of oil (percent) & 0 & 0.3 & 1.5 \\
\hline \multicolumn{4}{|c|}{ Ancillary data for gas accumulations } \\
\hline Inert gas content (percent) & 0 & 2 & 10 \\
\hline Carbon dioxide content (percent) & 0 & 1.5 & 10 \\
\hline Hydrogen sulfide content (percent) & 0 & 0.5 & 3.5 \\
\hline \multicolumn{4}{|l|}{ Depths } \\
\hline Depth (m) of water (if applicable) & 0 & 50 & 2,700 \\
\hline Drilling depth (m) & 350 & 2,000 & 7,000 \\
\hline
\end{tabular}


Table 4. Assessment results of the Lena-Vilyui Basin Province (conventional undiscovered resources).

[MMB, million barrels; BCF, billion cubic feet. Results shown are fully risked estimates. For gas fields, all liquids are included under the natural gas liquids (NGL) catagory. F95 denotes a 95-percent chance of at least the amount tabulated. Other fractiles are defined similarly. Fractiles are additive under the assumption of perfect positive correlation. TPS, total petroleum system; AU, assessment unit. N/A, not applicable]

\begin{tabular}{|c|c|c|c|c|c|c|c|c|c|c|c|c|c|c|}
\hline \multirow{2}{*}{$\begin{array}{l}\text { Total Petroleum } \\
\text { Systems and } \\
\text { Assessment Units }\end{array}$} & \multirow{2}{*}{$\begin{array}{l}\text { AU prob- } \\
\text { ability }\end{array}$} & \multirow{2}{*}{$\begin{array}{l}\text { Field } \\
\text { type }\end{array}$} & \multicolumn{4}{|c|}{ Oil (MMB) } & \multicolumn{4}{|c|}{ Gas (BCF) } & \multicolumn{4}{|c|}{ NGL (MMB) } \\
\hline & & & F95 & F50 & F5 & Mean & F95 & F50 & F5 & Mean & F95 & F50 & F5 & Mean \\
\hline \multicolumn{15}{|c|}{$\begin{array}{l}\text { Lena-Vilyui Basin Province, } \\
\text { zoic-Mesozoic composite tota }\end{array}$} \\
\hline \multirow{2}{*}{$\begin{array}{l}\text { Northern Priverkhoyansk } \\
\text { AU }\end{array}$} & 0.400 & Oil & 0 & 0 & 1,732 & 377 & 0 & 0 & 1,448 & 296 & 0 & 0 & 39 & 8 \\
\hline & & Gas & N/A & N/A & N/A & N/A & 0 & 0 & 4,319 & 1,039 & 0 & 0 & 116 & 28 \\
\hline $\begin{array}{l}\text { Total undiscovered } \\
\text { petroleum resources }\end{array}$ & & & 0 & 0 & 1,732 & 377 & 0 & 0 & 5,767 & 1,335 & 0 & 0 & 155 & 36 \\
\hline
\end{tabular}

\section{References Cited}

Allen, M.B., Anderson, L., Searle, R.C., and Buslov, M., 2006, Oblique rift geometry of the West Siberian Basin; tectonic setting for the Siberian flood basalts: Journal of the Geological Society of London, v. 163, p. 901-904.

Bakhturov, S.F., Yevtushenko, V.M., and Pereladov, V.S., 1990, Kuonam bituminous carbonate shale complex: Petroleum Geology, v. 24, no. 3-4, p. 124-133.

Baranova, Z.Ye., 1986, Prospects for non-anticlinal oil and gas pools in the Lena-Vilyuy oil-gas basin: Petroleum Geology, v. 21, no. 8, p. 362-368 [translated from Problemy geologii nefti i gaza Sibirskoy platformy: Leningrad, VNIGRI, p. $68-78,1982]$.

Baranova, Z.Y., 1996, Facies interrelationship of Tagandzhin and Monom formations of Lower Triassic of Viluyi syneclise: Petroleum Geology, v. 30, no. 3, p. 253-260 [translated from Bio-i lithostratigrafiya Mezozoya neftegazonosnikh rayov SSSR: Leningrad, VNIGRI, p. 14-25, 1990].

Barrett, P., 2003, Paleoclimatology—Cooling a continent: Nature, v. 421, p. 221-223.

Charpentier, R.R., Klett, T.R., and Attanasi, E.D., 2008, Database for assessment unit-scale analogs, exclusive of the United States: U.S. Geological Survey Open-File Report 2007-1404, 61 p.

Duchkov, A.D., Balobaev, V.T., Lysak, S.V., Sokolova, L.S., Devyatkin, V.N., Volod'ko, B.V., and Levchenko, A.N., 1982, The heat flow of Siberia: Geologiya i Geofizika, v. 23, no. 1, p. 42-51 [in English], p. 42-51 [in Russian].

Frakes, L.A., Francis, J.E., and Syktus, J.I., 1992, Climate modes of the Phanerozoic - the history of the Earth's climate over the past 600 million years: Cambridge, U.K., Cambridge University Press, 274 p.
Frolov, V.I., Syundyukov, Sh.,A., and Bakin, V.Ye., 1987, Catagenesis of organic matter in deep zones of the central Vilui syneclise: U.S.S.R. Academy of Sciences Transactions, v. 297 , no. 2 , p. $72-74$.

Girshgorn, L. Sh., 1996, Structural-formational characteristics of pre-Jurassic sediments of the north of West Siberia from seismo-geological analysis: Petroleum Geology, v. 30, no. 3, p 243-249 [Translated from Sovremennyye geofizicheskiye metody pri reshenii zadach neftyanoy geologii: Moscow, Nauka, p. 72-80, 1988].

Golonka, J., and Kiessling, W., 2002, Phanerozoic time scale and definition of time slices, in Kiessling, W., Flügel, E., and Golonka, J., eds., Phanerozoic reef patterns: Society of Economic Paleontologists and Mineralogists Special Publication 72, p. 11-20.

Gradstein, F.M., Ogg, J.G., and Smith, A.G., Agterberg, F.P., Bleeker, W., Cooper, R.A., Davydov, V., Gibbard, P., Hinnov, L.A., House, M.R., Lourens, L., Luterbacher, H.P., McArthur, J., Melchin, M.J., Robb, L.J., Shergold, J., Villeneuve, M., Wardlaw, B.R., Ali, J., Brinkhuis, H., Hilgen, F.J., Hooker, J., Howarth, R.J., Knoll, A.H., Laskar, J., Monechi, S., Plumb, K.A., Powell, J., Raffi, I., Röhl, U., Sadler, P., Sanfilippo, A., Schmitz, B., Shackleton, N.J., Shields, G.A., Strauss, H., Van Dam, J., van Kolfschoten, T., Veizer, J., and Wilson, D., 2004, A geologic time scale: Cambridge, U.K., Cambridge University Press, 589 p.

Grantz, A., Scott, R.A., Drachev, S.S., Moore, T.E., and Valin, Z.C., 2011, Sedimentary successions of the Arctic region $\left(65^{\circ}-90^{\circ} \mathrm{N}\right)$ that may be prospective for hydrocarbons, chap. 2 of Spencer, A.M., Embry, A.F., Gautier, D.L., Stoupakova, A.V., and Sørensen, K., eds., Arctic petroleum geology: Geological Society of London Memoir 35, p. 17-37.

Gusev, G.S., Koval'skii, V.V., Parfenov, L.M., Petrov, A.F., and Fradkin, G.S., 1985, Evolution of the crust of northeastern Siberia (Yakutiya): Soviet Geologiya i Geofizika, v. 26, no. 9, p. 3-11 (1-8). 
Hardenbol, J., Thierrt, J., Farley, M.B., Jacquin, T., de Graciansky, P.-C., and Vail, P.R., 1998, Mesozoic and Cenozoic sequence chronostratigraphic framework for European basins, in de Graciansky, P.-C., Hardenbol, J., Jacquin, T., and Vail, P.R., eds., Mesozoic and Cenozoic sequence stratigraphy of European basins: Society of Economic Paleontologists and Mineralogists Special Publication 60, p. 3-13.

IHS Energy Group, 2007 [includes data current as of October 2007], International petroleum exploration and production database [database available from IHS Energy Group, 15 Inverness Way E., Englewood, CO 80112].

Integrated Exploration Systems, 2008, PetroMod 1D, version 10: Aachen, Germany, Integrated Exploration Systems [purchased by Schlumberger in 2008].

Ivanov, V.L., 1979, Olenekskoe mestorozhdenie bitumov (Geologicheskoe stroenie i usloviia formirovaniia): Nauchno-issledovatel'skii institut geologii Arktiki, Trudy (Leningrad, "Nedra," Leningrad Branch), v. 182, 103 p. [translated for the U.S. Geological Survey by Dorothy B. Vitaliano, July 1985].

Izosimova, A.N., Safronov, A.F., Zuyeva, I.M., and Frolov, V.I., 1988, Catagenic alteration of organic matter: Petroleum Geology, v. 22, no. 11, p. 531-534 [translated from Geokhimiya organicheskogo veschestva neftegazonosnykh otlogeniy Zapadnoy Yakutii: Novosibirsk, Nauka, p. 53-74, 1984].

Kontorovich, A.E., 1994, Oil and gas bearing regions of the Siberia, issue 4, Lena-Vilyuy Basin (Neftegazonosnye basseiny i regiony Sibiri, vypysk 4, Leno-Viliuiskii bassein): Novosibirsk, 107 p. [In Russian.]

Kontorovich, A.E., Grebenyuk, V.V., Kuznetsov, L.L., Kulikov, D.P., Khmelevskiy, V.B., Azarnov, A.N., Nakaryakov, V.D., Polyakova, I.D., Sibgatullin, V.G., Soboleva, Ye.I., Starosel'tsev, V.S., and Stepanenko, G.F., 1994, Oil and gas bearing regions of the Siberia, issue 3, YeniseiKhatanga Basin (Neftegazonosnye basseyny i regiony Sibiri, vypysk 3, Yenisey-Khatangskiy basseyn): Novosibirsk, 71 p. [In Russian.]

Parfenov, L.M., 1985, Fault dislocations of the Verkoyany folded zone and problems of its petroleum content: Soviet Geologiya i Geofizika, v. 26, no. 12, p. 8-18 (5-12).

Parfenov, L.M., and Prokopiev, A.V., 1993, Frontal thrust structures of the Verkhoyansk foldbelt: Russian Geology and Geophysics, v. 34, no. 7, p. 15-25.

Parfenov, L.M., Prokopiev, A.V., and Gaiduk, V.V., 1995, Cretaceous frontal thrusts of the Verkhoyansk fold belt, eastern Siberia: Tectonics, v. 14, no. 2, p. 342-358.
Persits, F.M., and Ulmishek, G.F., 2003, Maps showing geology, oil and gas fields, and geologic provinces of the Arctic: U.S. Geological Survey Open-File Report 97-470-J, CD-ROM.

Safronov, A.F., and Bodunov, Ye.I., 1987, Short summary of geology of oil-gas sediments of west Yakutia: Petroleum Geology, v. 22, no. 11, p. 522-530 [translated from Geokhimiya organicheskogo veshchestva neftegazonosnykh otlozheniy Zapadnoy Yakutia: Novosibirisk, Nauka, p. 7-23, 1984].

Sokolov, B.A., ed., 1989, History of oil-gas formation and accumulation in the east of the Siberian Craton: Petroleum Geology, v. 23, no. 1, p. 12-45 [translated from Akademiya Nauk SSSR, Sibirskovo Otdeleniya, Yakutskii Filial, Institut Geologii, Moscow, Izdatelctvo Nauka, 166 p., 1986].

Sokolov, B.A., and Yapaskurt, O.V., 1988, Catagenesis of rocks and oil-gas potential of west margin of Verkhoyansk miogeosynclinal basin: Petroleum Geology, v. 22, no. 1, p. 31-36 [translated from Osadochnyye basseyny i ikh neftegazonosnos: Moscow, p. 226-237, 1983].

Sweeney, J.J., and Burnham, A.K., 1990, Evaluation of a simple model of vitrinite reflectance based on chemical kinetics: American Association of Petroleum Geologists Bulletin, v. 74, p. 1559-1570.

Ulmishek, G.F., 2001, Petroleum geology and resources of the Nepa-Botuoba High, Angara-Lena Terrace, and Cis-Patom Foredeep, southeastern Siberian Craton, Russia: U.S. Geological Survey Bulletin 2201-C, 16 p.

Ulmishek, G.F., and Klemme, H.D., 1990, Depositional controls, distribution, and effectiveness of world's petroleum source rocks: U.S. Geological Survey Bulletin B-1931, $59 \mathrm{p}$.

Vagin, S.B., Samsonov, Yu.V., Shashin, A.V., and Dongaryan, L.Sh., 1987, Paleo-geologic and paleo-hydrogeologic bases for assessing the oil-gas prospects of the Vilyuy Basin: Petroleum Geology, v. 22, no. 10, p. 458-460 [translated from Neftegazovaya Geologiya i Geofizika, no. 8, p. 2-4, 1986].

Wygrala, B.P., 1989, Integrated study of an oil field in the southern Po Basin, northern Italy: Berichte der Kernforschungsanlage Julich, no. 2313, 217 p.

Zonenshain, L.P. (Zonenshayn, L.P.), Kuzmin, M.I., and Natapov, L.M., 1990, Geology of the USSR-A platetectonic synthesis: American Geophysical Union, Geodynamics Series, v. 21, 242 p. 


\section{Appendix. Input data for the Northern Priverkhoyansk Foredeep Assessment Unit}


